\title{
Erratum to "Effects of Angiotensin-Converting Enzyme Inhibition on Circulating Endothelial Progenitor Cells in Patients with Acute Ischemic Stroke"
}

\author{
Monika Gołąb-Janowska (D), ${ }^{1}$ Edyta Paczkowska $\left(\mathbb{D},{ }^{2}\right.$ Bogusław Machaliński $\left(\mathbb{D},{ }^{2}\right.$ \\ Dariusz Kotlęga $\left(\mathbb{D},{ }^{1}\right.$ Agnieszka Meller $\mathbb{D}^{1},{ }^{1}$ Krzysztof Safranow ${ }^{(D)}{ }^{3}$ Michał Maj $\left(\mathbb{D},{ }^{1}\right.$ \\ and Przemysław Nowacki $\mathbb{D}^{1}$ \\ ${ }^{1}$ Department of Neurology, Pomeranian Medical University, Szczecin, Poland \\ ${ }^{2}$ Department of General Pathology, Pomeranian Medical University, Szczecin, Poland \\ ${ }^{3}$ Department of Biochemistry and Medical Chemistry, Pomeranian Medical University, Szczecin, Poland \\ Correspondence should be addressed to Monika Gołąb-Janowska; monikagj@op.pl
}

Received 1 June 2020; Accepted 22 June 2020; Published 4 November 2020

Copyright (C) 2020 Monika Gołąb-Janowska et al. This is an open access article distributed under the Creative Commons Attribution License, which permits unrestricted use, distribution, and reproduction in any medium, provided the original work is properly cited.

In the article titled "Effects of Angiotensin-Converting Enzyme Inhibition on Circulating Endothelial Progenitor Cells in Patients with Acute Ischemic Stroke" [1], additional references should have been cited, included in the text below as references 61-68 [2-9].

The details of where these references should have each been cited are as follows:

Reference 61. In Page 2, at the end of first paragraph, after the sentence "In addition, assessing endothelial damage is important when evaluating EPC levels [5]."

References 62, 63. In Page 6, at the last paragraph of the first column, after the sentence "This occurs in patients with acute coronary syndrome and acute ischemic stroke, with a peak in EPC counts and vascular endothelial growth factor(VEGF) levels occurring on the seventh day after the ischemic event $[16,38-40] . "$

Reference 64. In Page 6, at the first paragraph of the second column, after the sentence "In previous studies involving patients with myocardial infarction, a higher number of EPCs were associated with better prognosis, increased myocardial salvage, and more collateral in the ischemic zone $[41,42] . ”$

References 65-68. In Page 7, at the sixth line of the second column, after "Indeed, Mandraffino et al. [60]."

\section{References}

[1] M. Gołąb-Janowska, E. Paczkowska, B. Machaliński et al., "Effects of angiotensin-converting enzyme inhibition on circulating endothelial progenitor cells in patients with acute ischemic stroke," Stem Cells International, vol. 2018, Article ID 2827580, 10 pages, 2018.

[2] G. P. Fadini, C. Agostini, S. Sartore, and A. Avogaro, "Endothelial progenitor cells in the natural history of atherosclerosis," Atherosclerosis, vol. 194, no. 1, pp. 46-54, 2007.

[3] A. Taguchi, T. Matsuyama, H. Moriwaki et al., "Circulating CD34-positive cells provide an index of cerebrovascular function," Circulation, vol. 109, no. 24, pp. 2972-2975, 2004.

[4] R. P. Rouhl, R. J. Damoiseaux, J. van Oostenbrugge, J. W. Tervaert, and J. Lodder, "Endothelial progenitor cell research in stroke: a potential shift in pathophysiological and therapeutical concepts," Stroke, vol. 39, no. 7, pp. 2158-2165, 2008.

[5] Y. Numaguchi, T. Sone, K. Okumura et al., "The impact of the capability of circulating progenitor cell to differentiate on myocardial salvage in patients with primary acute myocardial infarction," Circulation, vol. 114, 1 Suppl, pp. I114-I119, 2006.

[6] G. Mandraffino, M. A. Sardo, S. Riggio et al., "Circulating progenitor cells are increased in newly diagnosed untreated hypertensive patients with arterial stiffening but normal carotid 
intima-media thickness," Hypertension Research, vol. 34, no. 7, pp. 876-883, 2011.

[7] A. L. Gullo, G. Mandraffino, M. A. Sardo et al., "Circulating progenitor cells in rheumatoid arthritis: association with inflammation and oxidative stress," Scandinavian Journal of Rheumatology, vol. 43, pp. 184-193, 2013.

[8] A. Lo Gullo, G. Mandraffino, G. Bagnato et al., "Vitamin D status in rheumatoid arthritis: Inflammation, Arterial Stiffness and Circulating Progenitor Cell Number," PLoS One, vol. 10, no. 8, article e0134602, 2015.

[9] G. Mandraffino, C. O. Aragona, G. Basile et al., "CD34+ cell count predicts long lasting life in the oldest old," Mechanisms of Ageing and Development, vol. 164, pp. 139-145, 2017. 